\title{
Perceptions of school resource officers on juvenile delinquents in schools
}

\author{
Serkan Taşğın ${ }^{1}$ \\ İsmail Cenk Demirkol ${ }^{2}$ \\ Gökhan Aksu ${ }^{3}$
}

\begin{abstract}
Violence is very common in the schools of the U.S. Therefore, families have suspicions not only about competency of the education but also for safety of their children in the school. While there is a great deal of studies which examined the effectiveness and success of school resource officers in schools, and studies which explore the perceptions of citizens, school administration, and juveniles toward police, fewer studies exploring the perceptions of school resource officers about different issues such as their perceptions toward juvenile justice system, school administration and staff, families of juveniles, and juvenile offenders. Fifteen school resource officers were interviewed in schools in a mid-sized Midwestern city in the U.S.. The researcher was allowed to conduct interview with police officers by Police Department's approval. The consent forms were delivered to participants which were reviewed and signed by the participants. Purposive sampling method was used by asking Deputy Chief in police department either who has worked or currently working in schools school resource officers. The interviews were digitally recorded. The researcher saved these interviews to the computer and transcribed them into the word processor. Findings revealed that there was no standardized training for school resource officers. Their criterion for using discretion was mostly based on the attitude of the families toward them or toward their children. They perceived minor offenses in schools as 'gateway' for future serious offenses. Since the study participants were not randomly selected and the sample size was 15 , findings cannot be generalized to all school resource officers in the U.S. However, it is expected that all school resource officers would have common experiences such as use of discretion, problems with school administration, and the prevalence of violence among youth. Thus, this study can provide some insights about the experiences of school resource officers from other States of the U.S. Further research in the area of school resource officers is needed to determine solutions to youth violence in schools.
\end{abstract}

Keywords: School Resource Officer; Discretion; Delinquency; Juvenile Justice System; School.

\footnotetext{
${ }_{1}^{1}$ Ph.D., Security Science Specialist, tasginserkan@gmail.com

2 Ph.D., Security Science Specialist, icdemirkol99@yahoo.com

${ }^{3}$ Ph.D., Security Science Specialist, gokhanaksu1@yahoo.com
} 
Taşğın, S., Demirkol, İ.C., \& Aksu, G. (2015). Perceptions of school resource officers on juvenile delinquents in schools. International Journal of Human Sciences, 12(1), 664-684. doi: 10.14687/ijhs.v12i1.3062

\section{Introduction}

School violence is like an equation which has many components such as gangs, drugs, bullying, physical fights, etc. Safety in schools is very important issue in societies because schools are the social environment where each family sends their children. Families expect good education for their children in schools. However, violence is very common in the schools of the U.S. Naturally; families have suspicions not only about competency of the education but also for safety of their children in the school. Besides families' concerns, Ryan et al. (2007) mentioned there is a great fear of violence among students. Moreover, teachers have also difficulties about safety in the schools while dealing with education of children. In this regard, with the fear of students and concerns of families and teachers, we cannot mention a good education in the schools without safety. So, what is school violence? Furlong et al. (1997) emphasized public health approach to define school violence as, "it includes physical and nonphysical harm which causes damage, pain, injury, or fear, and it disrupts the school environment and results in the debilitation of personal development which may lead to hopelessness and helplessness" (p. 246). In order to prevent school violence, there are numerous interventions and programs in order to prevent and reduce school violence and school resource officer program is one of them to prevent crime and provide safe environment in schools.

Given the violence in schools and assigning police officers to school, what are the experiences and perceptions of school resource officers about juveniles, their families, and juvenile justice system? While there is a great deal of studies which examined the effectiveness and success of school resource officers in schools, and studies which explore the perceptions of citizens, school administration, and juveniles toward police, fewer studies exploring the perceptions of school resource officers about different issues such as their perceptions toward juvenile justice system, school administration and staff, families of juveniles, and juvenile offenders. Therefore, the purpose of this phenomenological study is to discover attitudes, experiences, and perceptions of school resource officers toward juvenile delinquents, their parents, and juvenile justice system.

\section{Review of the Literature}

Police are the first major component of the justice system to deal with juvenile delinquents. Because of increasing rate of juvenile violence in both serious offenses and nondelinquent juvenile matters such as neglect, abuse; there needed to have specialized police units to deal with juveniles (Trojanowicz et al., 2001) and school resource officer program was one of the response to increasing rate of juvenile delinquency. 
Taşğın, S., Demirkol, İ.C., \& Aksu, G. (2015). Perceptions of school resource officers on juvenile delinquents in schools. International Journal of Human Sciences, 12(1), 664-684. doi: 10.14687/ijhs.v12i1.3062

There are different types of school violence such as bullying, assault, substance abuse which not only victimize the students, but also threaten the educational process. Dinkes et al. (2009) collected data from various sources such as national survey of students, teachers, principles, federal agencies (for example, BJS, NCES, FBI, CDC) which provided broad perspective on school violence in grades 9 through 12. For example, in 2006, there were 34 thefts in schools for 1,000 students while there were 29 violent crimes per 1,000 students in the same year. Substance abuse was another prevalent problem in schools. In $2007,22 \%$ of the students reported that they were offered, sold, or given drugs in schools while this percentage was 25 in 2005. Being called a hate related words was also common in schools. In 2007, between ages 12 and 18, 10\% of the students reported that someone had used hate related words against them in the school. Bullying was another substantive problem in school. For example, in 2007, almost 32 percent of the students between 12 and 18 years old reported that they were bullied in the school and 4 percent of the students reported that they were cyber bullied such as posting hurtful information about them on the internet, being insulted or threatened. Females were more cyber bullied than males. Physical fights also occurred in schools more often and in 2007, 12 percent of the students reported being in a physical fight (Dinkes et al., 2009; Dorn, 2004). Moreover, being in a physical fight among students in grades 9 through 12 decreased from $42 \%$ to $33 \%$ while physical fight on school property decreased from 16\% to 12\% between the years 1993 and 2011. Students who carried gun at least once in grades 9 through 12 declined from $22 \%$ to $17 \%$ and carrying gun on school property declined from $12 \%$ to 5\% between the years 1993 and 2011. In 2011, almost 39\% of the students in grades 9 through 12 had at least one drink of alcohol and 5\% of them had one drink of alcohol on school property while $23 \%$ of the students reported that they used marijuana at least once and 6\% reported that they used marijuana on school property (NCES, 2013).

Although it is not mostly indicated in crime data, according to survey of school resource officers in 2009, internet based crime increased fifty nine percent which shows that this is a prevalent problem which school resource officers encounter (SRO, 2009). Cyber bullying became a new topic which is very common among students. According to the survey of I-SAFE America which was conducted across the America between 2003 and 2004, it was found that $42 \%$ of the kids were bullied online, $35 \%$ of the kids were threatened online, and $58 \%$ of the kids have not told cyber bullying issue to their parents (I-SAFE, 2009).

While the school violence is widespread in schools, the common belief is that boys are more likely to engage in deviant behavior than girls both in school and out of school (Lotz, 2005). However, there is also another assumption which claims that girls commit more crimes than boys. 
Taşğın, S., Demirkol, İ.C., \& Aksu, G. (2015). Perceptions of school resource officers on juvenile delinquents in schools. International Journal of Human Sciences, 12(1), 664-684. doi: 10.14687/ijhs.v12i1.3062

In particular, the arrest rate of juvenile female offenders increased more or decreased less than males when compared between 1994 and 2003 (Snyder, 2005).

School counselors, psychologists were considered to deal with delinquents in schools. Larson and Busse (1998) examined how school psychologist training programs response school violence issues. They sent surveys regarding school violence and gangs to 303 school psychology training programs and they found that most of the programs focused on behavioral concerns like conduct problems and school violence and gangs were not their priorities. This finding is consistent with Furlong et al's (1996) study on school psychologists. They studied the perceptions, experiences of school psychologists and they found that $78 \%$ of the school psychologists in the sample felt themselves unprepared to deal with school violence. According to their findings, $85 \%$ of school psychologists also reported that they had no specialized training on school violence.

Since there was an increase in violence in schools, there was need to implement some programmes one of which was assigning police officers to schools. School resource officers are assigned full time to a particular school to help providing safe and secure school environment. Their primary goal is to maintain the security in the school. For example, in Chicago, with the Safe School programme, 120 police officers were assigned to particular schools. At the end of 4 year period, it was found that arrest rate for offenses which are occurred in school property such as aggravated battery, robbery, murder, and other serious crimes have fallen $46 \%$ (Crouch \& Williams, 1995).

School resource officer is a model which represents a kind of community policing with a collaborative relationship between police, school and intervention strategies. It was first developed in Flint, Michigan during the 1950s and since that time, it was expanded throughout the United States with increasing popularity and a national association with almost 15.000 members (Lambert $\& M c G i n t y, 2002)$. They have excessive interaction with school personal which makes them seen as a part of school staff. School resource officers is officially defined as, “.... a career law enforcement officer, with sworn authority, developed in community-oriented policing, and assigned by the employing police department or agency to work in collaboration with school and community-based organizations (U.S. Department of Justice, 1999, p.1). They work closely with school staff and parents in order to prevent crime, provide safety in the school. They also teach in the schools and their work in the school is more proactive than reactive. In this respect, school resource officers have four basic responsibilities in educational environment such as counseling students, performing their enforcement duties, they act as a liaison officer between police, school, and the community, and they also teach law related issues in the classroom (U.S. Department of Justice, 2001)School officers are selected if they are interested in working with juveniles. They need to indicate their 
Taşğın, S., Demirkol, İ.C., \& Aksu, G. (2015). Perceptions of school resource officers on juvenile delinquents in schools. International Journal of Human Sciences, 12(1), 664-684. doi: 10.14687/ijhs.v12i1.3062

interest by word of mouth and they are not informed that they would be paid for overtime work so that there will not be much monetary gain which may influence their decision making of being school officer (Johnson, 1999)

School resource officer program is implemented with great expectations and there are many studies which focus on the success and function of this programme in schools. However, there are not enough studies which measure the perceptions of school resource officers toward, juveniles, their families, and juvenile justice system. May et al. (2004) stated that little is known about attitudes and characteristics of school resource officers in educational environment. They studied whether or not school resource officers activities is relevant to community policing and therefore they conducted survey among school resource officers who worked in Kentucky and found that school resource officers in Kentucky is mostly have different identities such as partly counselor, partly enforcer, and partly teacher which shows that school resource officers have different responsibilities. They also found that in order to have desired outcomes for having school resource officers in the school while they will have different roles and responsibilities, these officers should be socialized.

Families have a crucial role in preventing juvenile delinquency if they provide care, discipline and supervision. Juveniles who are not attached to their parents, living in families where there are not clear disciplinary rules and who are less supervised are more likely to commit crimes. Therefore, many disciplines studied relationship between families and criminal behavior. Many crime theories emphasize the role of families on criminality such as Hirchi's social control theory, Sampson and Laub's life course theory, Aker's social learning model, or Gottfredson and Hirschi's general theory of crime. Moreover, according to U.S. Census, births to unmarried women increased 26 percent in 1970 to 44 percent in 2000. The percentage of single parent households increasing in the U.S., and some studies are examining the relationship between criminals and their structures of family. (Simons et al, 2004). For example, Barber (2004) cited Lykken's study which stated that single mothers' children are about 7 times as likely to be incarcerated compared to children raised by married couples. While some studies insist on that most criminals have single parents, some studies focus on the quality of parenting. Therefore, it is important not to focus the structure of families but also focusing on parental quality (Simons et al, 2004).

Police has a great deal of discretionary power which ranges between releasing juvenile unofficially at initial contact to arrest and refer to the juvenile court (Trojanowicz et al., 2001). Police use of discretion was almost related with attitudes of juveniles, types of offenses, criminal background, etc. Piliavin and Briar (1964) observed the use of discretion of police officers and found that juvenile offenders' prior records, race, grooming, and demeanor was major criterions for 
Taşğın, S., Demirkol, İ.C., \& Aksu, G. (2015). Perceptions of school resource officers on juvenile delinquents in schools. International Journal of Human Sciences, 12(1), 664-684. doi: 10.14687/ijhs.v12i1.3062

determining police discretion. However, this study was weak because of not using police officers as primary source of information. Fisher and Mawby (1982) examined use of discretion of police in their study and found that age of the offender, complaint's wish, parental concern; child attitude, offense types, and previous record of the juvenile were the factors which influence police discretion for juvenile delinquents. Kraus and Hasleton (1982) studied which factors affect police discretion on which juveniles deserve lenient treatment and they found that nonseriousness of the offense, favorable impression, and being single offender were significantly related with lenient treatment. Discretion is not used only by police but also other government officials such as parole officers, counselors, prosecutors etc. Lipsky (1980) defines them as 'street level bureaucrats'. He gives probation officers an example because they have heavy caseloads which force them to make quick decisions. This also results with inefficient control mechanism of criminals.

Police's use of discretion mostly was examined by the previous criminal records, offense types, age, race of the offenders, or attitudes of juvenile which is also indicators of labeling of juveniles by the police. Therefore, the existence of use of discretion and police behavior based on discretion may be examined through the lenses of labeling theory (Landau, 1981; Brownfield \& Thompson, 2008). In the earliest version of labeling by Tannenbaum (1938), the act itself was labeled by as deviant by others rather being deviant. With the wide range of use of discretion, labeling theorists made contributions into the criminology and criminal justice system how juvenile justice system components such as police, courts, and probation officers make decisions and which reflect bias (Trojanowicz et al., 2001). Klein (1986) found that labeling paradigm was existing based on juveniles' SES, gender, ethnicity, and previous criminal record which influence the juvenile justice components' view. Moreover, constructionist theory tries to understand how people become delinquent, tries to explain deviance as dependent variable, what is happening in the big picture of society, how some people are labeled, stigmatized. In this respect, school resource officers' construction of juveniles is important to examine. Another theory which is relevant with juvenile delinquency is life course theory. Sampson and Laub (2005) examined persistent offending and desistance from the crime in their study. One of the major findings was that when offender experience structural turning point, because of this change, he/she is subjected to increased informal social control which they can be monitored and controlled for deviant behavior and they establish a new lifestyle. In this respect, the presence of school resource officers in schools is important to help juveniles establishing new lifestyle by monitoring and helping them.

Law enforcement officers who deal with juveniles usually complain about the juvenile justice system for several reasons. In his study in Georgia, Clark (2007) found that, law enforcement personal thought that juvenile justice system is too lenient on juvenile offenders and they stated 
Taşğın, S., Demirkol, İ.C., \& Aksu, G. (2015). Perceptions of school resource officers on juvenile delinquents in schools. International Journal of Human Sciences, 12(1), 664-684. doi: 10.14687/ijhs.v12i1.3062

that they wanted to see juveniles as tried as adults for serious crimes. There are also debates about giving severe sentences, having adult like law, and sending juveniles to adult courts who commit serious crimes which is also supported by public (Mears, 2001). In their longitudinal study, Johnson et al. (2004) studied persistent offending of juvenile offenders and they found that there was continuity for offending over time and involvement into the juvenile justice system had positively related to further crime which means lack of deterrence of juvenile justice system.

Given the knowledge about school resource officers, juvenile justice system, and juvenile delinquency, there is not academic research which measures the perception of school resource officers' perceptions and experiences about several issues such as how they use their discretion, what are their experiences for juvenile delinquency, and how they perceive juvenile justice system in which they operate. Therefore, this study will shed light on these issues by learning their experiences and perceptions.

\section{Methodology}

This research consists of 15 interviews which were conducted with school resource officers who worked in a mid-sized Midwestern city in the U.S. in 2012. All of the interviews were digitally recorded. Interviews followed an open ended, structured schedule and lasted average of 45 minutes. All interviews were transcribed in full. The units of analysis of this study is police officers who are either currently working as school resource officers or have worked in schools, because in a phenomenological study, the participants must have all experienced the phenomenon and can articulate their lived experiences (Creswell, 2007).

Interviewed school resource officers have professional experience ranging from 8 years to 15 years with an average of 11.4 years of professional experience and have school experience ranging from 3 years to 5 years with an average of 3.6 years. The sample ranges in age from 33 to 45 with an average 38 years. 3 of the fifteen school resource officers were working in the police department as patrol officers who previously worked in schools, and 12 officers were currently working in the schools. All interviewees are white and 2 of the police officers were female. The interviews were voluntary and they were promised strict confidentially ${ }^{4}$. The researcher is allowed to conduct interview with police officers by Police Department's approval. The consent forms were delivered to participants and they were reviewed and signed by the participants. I used purposive sampling method by asking Deputy Chief in police department either who has worked or currently working in schools school resource officers because participants can "purposely inform an understanding of the research problem and central phenomenon in the study" (Creswell, 2007, p.

\footnotetext{
${ }^{4}$ Pseudonyms are used throughout the paper for school resource officers.
} 
Taşğın, S., Demirkol, İ.C., \& Aksu, G. (2015). Perceptions of school resource officers on juvenile delinquents in schools. International Journal of Human Sciences, 12(1), 664-684. doi: 10.14687/ijhs.v12i1.3062

125). School resource officers were asked several questions such as why they chose to be a school resource officers; what kind of training they had; how they interact with juveniles at school; how they perceive juvenile delinquency and what kind of crime they came across at school; what kind of difficulties they encounter while dealing with juvenile delinquents; how they interact and perceive school administration and families of juveniles. The interviews were digitally recorded. The researcher saved these interviews to the computer and transcribed them into the word processor. Transcription was done verbatim after the interviews and printed out for analysis.

\section{Analysis}

\subsection{Why being a SRO}

In order to be school resource officer, police officers need to be a volunteer for this post and apply for it with statement of interest letter. They all sent their statement of interest letters to their supervisors but with different intentions. The reasons for being school resource officer varied as having impact on somebody's life, looking for change, having regular working shift. However, sometimes application for this post is not voluntary. For example, when the post is announced, it might be mandatory for junior officers to apply for it if there is no one else to apply. For example, Alex stated that,

I actually I did not have any interest in working in the school. When I was a two years police officer here, a position in the schools opened. I was the lowest senior officer at that time, and I kind of felt like I should put in to it because then they would me do it. So that I wanted that and it ended up with applying for that position.

Working as a school resource officer has some advantages compared with working on patrol. Usually, we know that police officers apply for this post for working in the school to help juveniles, but they may have different intentions such as being tired of working on patrol, working at night. Chris stated that,

I did a road patrol for ten years and I was looking for a change, looking for something different to do. It has a normal schedule it is Monday to Friday you work from 8.30 am to $3.30 \mathrm{pm}$. I really wanted a change from working in road patrol, taking calls; making traffic stops the stuff like that.

Police work on the street is not easy and police officers who have worked many years on patrols wanted to work in schools which have regular working hours in days not evenings or nights. While most of the police officers interested in being school resource officers, they had mainly had the idea of working in more regular place than working in patrol. 
Taşğın, S., Demirkol, İ.C., \& Aksu, G. (2015). Perceptions of school resource officers on juvenile delinquents in schools. International Journal of Human Sciences, 12(1), 664-684. doi: 10.14687/ijhs.v12i1.3062

\subsection{Types of Interaction with Juveniles}

Most of the school resource officers tried to build relationship with juvenile offenders, giving advices and solving problems of the juveniles. Their primary interest group was juvenile offenders or victims rather than whole juvenile population in the school. They usually helped juvenile delinquents to ameliorate their ruined relationships in the school as Larry says,

I came across a kid that last year was getting all good grades. Then, he was assaulted last year by another student and ever since then his grades went down. Couple of days ago, I called his mother and talked to her and her response was that he was studying, he is not skipping classes everything she ask be does and he is smiling now when he comes to classes, he was kick out from the wrestling team but I talked to bis coach an now he is back on the team.

\subsection{Inservice Training}

All of the school resource officers stated that they had inservice training not only for juvenile offenders but also juvenile victims in order to deal with juvenile delinquents and victimization. They all mentioned that they did not have any training in the police academy where they graduated from. As Taylor stated, My police training did not really deal with juvenile law or issues related with juveniles.

With the lack of knowledge about issues related with juveniles, school resource officers had different kinds of training for both juvenile victims and offenders. They all agreed that while these kinds of trainings are helpful, they are still in need of some kinds of trainings. For example, some of the respondents recommended inservice training on social network of juveniles, technology use, and juvenile law. They all admitted effectiveness and usefulness of those inservice trainings to deal with juvenile victims and offenders. Most of the respondents were agree that these trainings would also be helpful for other police officers regardless of their division because they might encounter with juveniles as a victim or offender at any time. Mike stated that,

The training I would like to see for myself would be networking, social networking that the kids have especially electronic social networking whether it is through internet, the email, cell phones, text messaging, Facebook, My space, because lot of complaint that I receive in the school are threat complaints with using electronic means whether that means cell phone text messaging or email. I think it would be nice to see that kinds of training in whole department.

\subsection{Perceived Definition of Juvenile Delinquency}

Juvenile delinquent term was used differently among school resource officers such as juvenile offenders, juvenile criminals, or minor suspects. When school resource officers were asked 
Taşğın, S., Demirkol, İ.C., \& Aksu, G. (2015). Perceptions of school resource officers on juvenile delinquents in schools. International Journal of Human Sciences, 12(1), 664-684. doi: 10.14687/ijhs.v12i1.3062

about how they perceive juvenile delinquency, most of them stated their unwillingness to use 'delinquent' term because they pointed out that it sounded more negative term than other terms. Spencer stated that, We call them if it fits as minor suspect. Yes, they are just suspect. I think delinquent is pretty negative word.

Having negative feelings with the term of delinquency, six school resource officers mentioned how this term can label the juveniles in negative manner. We can see how offender and delinquent can differ in the explanation of Walsh:

I would not use that term. Juvenile delinquent is just almost like saying they are all bad guys. I would say juvenile delinquents would mean they are messed up in their whole lives. I would say jwvenile offenders and that means that they have an offense but that does not mean they are delinquent in their whole lives. I don't want to put a label on a kid. Delinquency is like a general stamp on person.

\subsection{Most Common Crime Types in Schools}

Larceny from auto (LFA), psychical fights, drugs, threats, bullying, and alcohol are the most common offenses which juveniles commit in this area. Due to following juveniles throughout their years in the schools, most of the school resource officers were able to track them and their persistent offending. Therefore, they were able to identify which crimes were start point for later crimes. five of the fifteen police officers mentioned 'gateway' term for some offenses which can lead other serious offenses. As Jennifer stated,

I think a lot of crimes that juvenile commit they are almost like gateway crimes. LF A may be a gateway for stealing a car. Marijuana is gateway drug to core drugs like cocaine, crack, or heroin. Or assault as a juvenile may be a future indicator or domestic violence against future spouse or lover.

One of the advantages of being school resource officer is that they can see juveniles every day and they can see the types of offenses which they commit. Therefore, their experience for observing juveniles and their criminal history can give clues for seriousness of their crimes over time. While most of the studies are cross sectional for juvenile delinquency and with the lack of enough longitudinal studies, it is important to see that those juveniles start offending with less serious crime and they continue with other serious crimes.

There is a general belief that boys commit more crimes than females. However, none of the school resource officers were agreed with that belief. They told that before starting to work in the school, they believed that boys were more likely to commit crime than girls, but then, it changed. As Jack mentioned, Before I started this position, I would say yes, but now I say no. We had just this year along probably about nine fights and among nine fights I think only one was between the boys. Moreover, Chris stated, Threat and assault are mostly done by girls. 
Taşğın, S., Demirkol, İ.C., \& Aksu, G. (2015). Perceptions of school resource officers on juvenile delinquents in schools. International Journal of Human Sciences, 12(1), 664-684. doi: 10.14687/ijhs.v12i1.3062

\subsection{Cyber Bullying}

While there is a prevalence of cyber bullying among students, they usually do not show who the perpetuators are. When school resource officers were asked about girl violence in schools, they mostly mentioned cyber bullying among girls. It was surprising for school resource officers to see girls fighting while never hearing or seeing them arguing. John says,

You see them fighting in the school but you never see them arguing before. They may threaten by using Facebook, or by text messaging. Pretty much they are bullying each other on web.

The use of technology does not end with threatening or bullying each other. It may also result with some dangers which is not seen a serious problem such as distributing child pornography as Larry mentions,

A lot of kids do not realize how severe that is [distributing child pornography] because you know they are under 18, they take picture of themselves naked and send it to their boyfriend, and you know under 18 that is child pornography. So they do not realize it is 15 year felony. And they are sending to boyfriend that is they are distributing child pornography which is 15 year felony. So it is useful to let them know this is you know I know it seems harmless but they can turn into something serious.

Another problem that school resource officers come across is that while there are many incidents of bullying in the school, bullying is not considered as a crime so that police officers are in dilemma how to deal with this problem. They all mentioned that they were aware of this issue and found alternative solutions which they can enforce other sanctions which are indirectly related with cyber bullying. Brick says how he deals with this issue:

There is a law called malicious use of technological device. So if you text a threat, that is a felony. If you use a computer for threat, that is a felony. So there is a lot of things to do, I know whole page of laws, which are associated with bullying. When I teach on it, I say to cops if you need to use these things you can. So there is a lot of stuff that I can threat the kid with.

\subsection{Do Students Commit Crime in Group or Solo}

All of the school resource officers agreed that juveniles commit crime in groups or solo depending on the type of the offense, but they mostly mentioned offenses which were committed in groups such as larceny from auto, psychical fights, alcohol, breaking the houses, and bullying occurred in groups and drugs. As Alex says, It depended on the issue. I would say little bit both. Some of them do it together and some of them were doing on their own.

School resource officers mentioned that they did not see juveniles are fighting in groups inside or outside of the school. However, there was one interesting group dynamic in physical 
Taşğın, S., Demirkol, İ.C., \& Aksu, G. (2015). Perceptions of school resource officers on juvenile delinquents in schools. International Journal of Human Sciences, 12(1), 664-684. doi: 10.14687/ijhs.v12i1.3062

fighting in the school as Larry mentions two groups comes together and instigates the fight between two individuals from each group,

One group bere and one group here and one person from this group fights with one person with another group. These groups just talk, "hey I would not let you talk to me in that way" "You are gonna talk to me that" They are just instigating. You know, but fight occurs only within these two people. Quite often it rotates just like the same groups may fight again but next time there will be two different people. They are still the same groups.

\subsection{Attitudes of Juveniles After Crime}

Most of the school resource officers admitted that juvenile offenders rationalize their actions and show remorse. However, as Chris stated, there was a difference among offense types for showing remorse.

Most of the kids try to neutralize their actions a lot of times it is easy to get them to admit what they did. They show you remorse especially if it is a property crime if it is not a crime against another person a lot of kids they got caught often times when they are caught for shoplifting and when we sit in principal's office and talked to them and tell the circumstances of shoplifting, often times they begin to cry.

\subsection{Comparing With Adults}

School resource officers usually are assigned to school after working on patrol which means that they usually deal with adult criminals. Therefore, it is important to learn their perceptions whether or not they see juvenile offenders as adult offenders. They mostly said that juveniles are more open to influence, they have less serious level of crimes. However, they also mentioned that juveniles can be as violent as adults and there can be slight differences such as interrogating them. Sometimes public view which favors tolerant approach towards juveniles are not welcomed by police. Perceiving juveniles as not so different than adult criminals may be because of some events as Taylor mentions,

Juveniles can be as violent as adults and the main mistake that officers make sometimes and public don't understand they can be just as violent as adult can be. They are quicker sometimes. You bave got sympatby for them because they are kid you know, but they can be just as violent you know, we lost a member of our Department back in December. He actually moved to another police department in a big city but he was police officer here but he was killed by his own gun. I think the kid was seventeen so they can be just as violent as adults can be. 
Taşğın, S., Demirkol, İ.C., \& Aksu, G. (2015). Perceptions of school resource officers on juvenile delinquents in schools. International Journal of Human Sciences, 12(1), 664-684. doi: 10.14687/ijhs.v12i1.3062

\subsection{Difficulties of Handling Juvenile Offenders}

There are some difficulties for school resource officers when dealing with juvenile offenders such as difficulty in interviewing if they are suspect, parents' attitudes toward police, more paperwork, and difficulty in process. The official procedure of handling juveniles is different than adults so that this may bring some problems with it. As Alex says,

The process was not very easy. It was kind of not clear as dealing with how to deal with adults. If adult commits a crime they get arrested, they go to jail, they see a judge, where the juvenile they do not go through all that.

Chris mentions the difficulties in the procedures and dealing with those problems which is related with the parents of the juveniles who commit crime,

One of the biggest problems for dealing with juvenile is here; I think is to interview or interrogate the juvenile if they are suspect of the crime because you ask permission from their parents. Often times it is very hard to gather all parents and ask them for permission and often times they deny that what their children did. So that is the roadblock sometimes. Another roadblock is when a juvenile commits a crime we have to contact some kinds of parents or guardians to pick bim up and sometimes it is hard to find somebody.

Larry says although it is hard to deal with juveniles because of official procedures, sometimes it is easier to get them admit their crimes than adults.

It is harder to deal with juvenile than adults simply because well I guess it is harder because a lot of paperwork makes it harder. When you deal with a juvenile they are easy to confess the crimes they commit. So sometimes just walking up to them it is enough to make them in tears you can make impression on them easily. A lot of times it is easy to get them to admit what they did.

\subsection{Perception About Counselors, Teachers, And School Administration}

All of the school resource officers mentioned that they have quite well relationship with school administration and they think they are well trained to deal with students. School administration is responsible for implementing school policy while school resource officers enforce the law if necessary. However, there were also some opinions which can be clues about the role of police in the school and how school administration may try to behave as school resource officers. Jack mentions the division of roles in the school,

When we first start there, sometimes you have to remind them something or they have to remind you sometimes that I can't do anything for school policy. That is not my role but I you got someone stealing out of teacher's purse that is I can deal with. If juvenile commits a crime, we explain parent and juvenile that getting a fight with somebody means you broke the school policy and you broke the law. So schools deal with the policy part of it and police officer would deal with law part of it. 
Taşğın, S., Demirkol, İ.C., \& Aksu, G. (2015). Perceptions of school resource officers on juvenile delinquents in schools. International Journal of Human Sciences, 12(1), 664-684. doi: 10.14687/ijhs.v12i1.3062

Some school resource officers told their experiences in which they observed juvenile offenders are being rude and yelling at school administration which may be an indicator of lack of authority of school staff. This inefficiency of the school administration may be because of outside pressure on them and financial issues. John explains why authority of school administration is limited,

I have a lot more authority; I have a lot more consequences. They [juveniles] know I can take their freedom away. The principles and administration here they are limited what they can do. And they have got interest in the students that I don't have. I am not saying at personal level, I am talking about financial level. The State gives $\$ 7.000$ for each student. So if I send 30 students that is $\$ 210.000$ at all. School board decides who becomes a principle; school boards are elected so they had more political influence. So it is lot harder for them that they have to be as gentle as they can to the students and as result there are opportunities for students to take advantage of their kindness.

Moreover, lack of authority of school administration is not only aspect of incompetence of dealing with delinquent juveniles or outside influences. Mike has some concerns about ability of school staff dealing with offenders because he thinks that they are not trained to deal with offenders,

Counselors and teachers are not trained to deal with criminals but police are. I think a lot of teachers, a lot of counselors, and a lot of principles think that they are trained to deal with criminals and they think that they know what they were doing when it comes to dealing with juvenile out of control, but they don't. I find often times teachers and principals almost think, that they are detectives, interview kids and they may know how to interview kid when it comes to getting them some information but they have no idea how to interview a child.

In this respect, with having more authority and experience for dealing with delinquents, school resource officers may play a bridge role between juvenile offenders and school administration where school administration fails to respond, communicate, or control juvenile offenders in schools, because school resource officers will spend more time with them more than school administration does as Spencer says,

If the kid is messing up and does not care about the consequences of what school administration and teachers do, then administration and teachers cannot be effective. I think it is important for school resource officer to realize that we are kind of that buffing zone. I deal just small amount of them usually kids in trouble. So it is easier for me to build a relationship with them. They know they can tell me stuff...They used to see my face and my face becomes a familiar face for them and they be more willing to talk to me. 
Taşğın, S., Demirkol, İ.C., \& Aksu, G. (2015). Perceptions of school resource officers on juvenile delinquents in schools. International Journal of Human Sciences, 12(1), 664-684. doi: 10.14687/ijhs.v12i1.3062

\subsection{Underreporting Crimes}

According to survey of school resource officers in 2009, ninety two percent of school resource officers stated that the crime was underreported (SRO, 2009). Moreover, while literature usually mentions that there is a tendency for underreporting crimes which occur in the school, none of the school resource officers agreed with this assumption. Jennifer, who also got education at one of the top ten criminal justice schools in the U.S. said that,

There was a CJ class at the university and the teacher said, yeah all the high schools always underreport everything. We report everything. Especially in this high school, I have been there for 5 years. Every time we reported.

While underreporting issue is one of the controversial issues in school violence, there might be some reasons which force school administration and school resource officers to report incidents which occur in the schools such as liability issue as Taylor mentions, I make my reports every time and principles get my reports. They can't underreport the incidents because it puts all liability on them and this is not good for them so I think that never happen.

\subsection{Causation}

All of the school resource officers stated that the causation for juvenile delinquency were mostly because of families and peers. Although they did not consider other factors for causation, their experiences were also consistent with the literature which focus on family and peer influence on juvenile delinquency as Taylor states,

They may have some problems in their families; they may have some family members who broke the law, so it may cause crime. I doubt more about the family part of it just because of their age. Families bave huge impact on kids. If kids don't have consistency, don't have morals at home, that may be a problem. They may experience of substance abuse, alcohol because of their friends and peers may have a big part for causation.

\subsection{Family Type}

Most of the school resource officers usually mentioned discipline in the family and defined families as healthy or (un)disciplined families. They rarely mentioned the types of families such as single moms, broken families, etc. In this regard, school resource officers focus on whether families discipline their children or not, instead of focusing on types of families as Larry says, "I think discipline in the family is more important than the family structure". However, types of families is also mentioned by one of the school resource officers which he mentioned that, most of the juvenile delinquent that he came across were children of single moms as Brick says, 
Taşğın, S., Demirkol, İ.C., \& Aksu, G. (2015). Perceptions of school resource officers on juvenile delinquents in schools. International Journal of Human Sciences, 12(1), 664-684. doi: 10.14687/ijhs.v12i1.3062

I came across with juveniles who were mostly from single parents. In America the divorce rate is almost $50 \%$. I know a lot of kids in the school when we are in conversation I say tell your mom and dad and some kids say I don't know who my dad is. Typically it is single moms which I usually came across.

\subsection{Opinion about JJ System}

School resource officers were asked about their personal views of how juvenile justice system is dealing with juvenile offenders. There is a concern that juvenile offenders abuse the system Most of the school resource officers mentioned that juvenile justice system is not effective and deterrent to reduce juvenile crime. Juveniles are sent to different detention center unlike adult criminals which are also called as "juve" among the police officers. While detention centers supposed to be deterrent for reducing further crimes, these places might be a invaluable place for juveniles in which they meet other juvenile criminals as Mike noted that,

I think there are too many kids in the system. And a lot of kids realize it does not work very well. They spent time in juve home. They are not afraid of it anymore because they are nice to them. Once they got to the juve, they know other kids, very bad kids. That is disappointing but I do not know other option.

While there is a debate about the efficiency of juvenile detention centers, current situation of the detention center in the city is not promising due to not having enough room for juvenile delinquents. In this regard, while Chris suggests building more juvenile detention centers will help to reduce juvenile crime, Jack comes to same conclusion for the efficiency of detention of juveniles,

I wish there was more space in America for juvenile offenders who go to juvenile jail. Here we have one juvenile ball, which is also called juvenile detention center in this county and it has only 34 beds. There are only 34 spots... if they are sentenced to juvenile detention center for their crimes even if it is for just one week, it would deter them in the future. But I think kids in America learn that if I commit a crime whether it is misdemeanor or felony, I am not going to jail. They think they are juvenile and unless you kill somebody, you are not gonna to jail. So many kids are assaulting people, spraying buildings, breaking into the cars, threatening and nothing is happening to bim. Nothing happens to him.

Another control mechanism to follow juvenile delinquents is to put them on parole. Two school resource officers stated the inefficiency of probation system to follow juveniles. Walsh states that, Juvenile probation officers have heavy case load. They are watching hundreds of kids. They can't do that. It is frustrating.

Due to shortcomings of juvenile justice system which school resource officers perceive and experience, most of the school resource officers were not optimistic about the both current system and the future of this system. Alex has following reasons as indicated below, 
Taşğın, S., Demirkol, İ.C., \& Aksu, G. (2015). Perceptions of school resource officers on juvenile delinquents in schools. International Journal of Human Sciences, 12(1), 664-684. doi: 10.14687/ijhs.v12i1.3062

I think it is um.., becoming more complex through the years and as a result it is getting harder and harder to deal with the situation just because it is becoming more complex. Whether it is parenting, whether it is technology, laws or rules, or people's rights things are popping up which basically change the things, but in any government or bureaucracy, things don't change too fast... We need to have laws that we can use to help. Times had changed but the laws did not.

In order to be efficient to reduce or prevent juvenile crime, Chris proposed building more juvenile detention centers for having effective juvenile justice system which is based on punishment Lots of these kids I think if they are sentenced to juvenile detention center for their crimes even if it is for just one week, it would deter them in the future. Instead of building adult prisons, let's build more juvenile balls. When kids do things, we can put them in jail for a week and they may think that I don't wanna do come to juvenile hall again. There is nothing out there to deter kids.

\subsection{Discretion}

There are many components which influence police use of discretion when dealing juvenile offenders. However, unlike the literature, most of the police officers stated that their discretion is based on family reaction toward them which may make the situations more difficult for police, because they mostly accuse police. The family reaction may be in negative ways when they are called to the police station as Walsh states that, They [families] say how you dare to deal with my baby girl. I say she was stealing the store, and then they say prove it.

Therefore, because of negative attitudes toward police and trying to protect their children regardless of criminality may have negative impact on police discretion. Police may also think that juvenile will not learn that his/her behavior was wrong therefore, will use his discretion in negative way for juvenile to get his/her lesson for what they did as Larry says,

My perception is usually more determined after seeing the reaction of the parents... Defending the kid and you know this kid will always gonna be in trouble because mum and dad support them you know so my perception on juvenile is more based on the parents reaction than the juvenile reaction.

Walsh has the same opinion with Larry and says that he does not charge juvenile if he sees that parents are going to deal with their child at home which is an indicator of they know what their children did,

I always wait to see what the family does then I decide what I would do. They [children] do not feel bad for what they did but because they were canght. I have parents, who say how dare you talk to my kid, how dare you this, how dare you that. Those kids will never learn any kind of lesson at home. So I charge them as much as I can charge them with. Ifparents do not teach them then court system has to do. 
Taşğın, S., Demirkol, İ.C., \& Aksu, G. (2015). Perceptions of school resource officers on juvenile delinquents in schools. International Journal of Human Sciences, 12(1), 664-684. doi: 10.14687/ijhs.v12i1.3062

\section{Discussion}

School resource officer programs were usually examined for their outcomes to reduce violence in the schools and unfortunately school resource officers' perceptions and experiences when dealing with juveniles in the schools were not addressed in the studies. Unlike other police officers, they spend most of their time in the schools and they have different experience than other police officers. Therefore, while there are many studies which examine police perception and experience in many areas, our study shows how school resource officers' perceptions and experiences are similar or differ from other police officers.

Most of the school resource officers had inservice training but they were not standardized which means there is no standard for having certain courses when being assigned to schools as school resource officers. Therefore, there should be basic regular inservice trainings which consist of diversified topics related to youth problems. Moreover, some courses may be also necessary for other police officers when dealing with juvenile offenders. Due to dealing with mostly adults, police officers used to know criminal law for adults and have less practice or knowledge about juvenile law. Therefore, there has to be inservice training for police officers to remind them juvenile law.

One of the interesting findings of this study was that participants used 'gateway' term for some offenses which can lead serious offenses in later life. For example, marijuana can be gateway offense for cocaine, crack use and larceny from auto can be gateway for stealing auto. While life course theory focus on trajectories which drive juvenile into offending, gateway crimes may be considered as important point to deal with juvenile crime. Therefore, intervention programs can focus on some crimes which can be gateway for other serious crimes in the life course of the juveniles.

One of the most significant finding of this study was the criteria of use of discretion for juvenile offenders. Literature suggests many issues for discretion such as prior record, attitude of the offender, seriousness of the crime, etc. These factors are mostly related to juveniles not other factors. Unlike the literature, school resource officers mentioned that their criteria for using discretion was mostly based on the attitude of the families toward them or toward their children. This is the indicator of how they construct juveniles and their families in their minds to charge. For example, if families accuse school resource officers or support their children who commit crime, then school resource officers are more likely to charge the juveniles. While Johnson (1999) stated in his examination of school resource officer programme that, $82.4 \%$ of the school resource officers reported that parents were supportive of the SROs and responded them in positive way, we found that negative attitude of families toward school resource officers may result with harsher punishment for their children. Therefore, this issue must be taken into account when examining 
Taşğın, S., Demirkol, İ.C., \& Aksu, G. (2015). Perceptions of school resource officers on juvenile delinquents in schools. International Journal of Human Sciences, 12(1), 664-684. doi: 10.14687/ijhs.v12i1.3062

discretion of police. In this regard, constructionist theory might be used to explain how school resource officers use discretion based on their constructs about juveniles and their families.

While literature about juvenile delinquency claims that boys are more likely to commit crimes than girls, school resource officers told that they agreed this assumption before working in the school and said that working in the school changed their assumption because most of the crimes were committed by girls in particular cyber bullying or fights. While this finding is not reflected in the official data, special attention should be paid to examine increase violence among girls in the schools.

School resource officers' perception about juvenile justice system is consistent with the literature. They mentioned the policies and laws are behind the changes in the society, the system is not deterrent and juveniles are aware of it, and officers have some difficulties to find places to put juvenile offenders. One of the interesting finding was that seriousness of taking naked pictures and sending them to friends are not well examined in the literature of juvenile delinquency while it has severe sanctions in the legislation. They said while sending naked pictures is prevalent among students, they do not know whether or not enforcing this sanction toward juveniles. Therefore, there has to be clear identification and sanction for sending naked pictures among juveniles.

Like all research, this article has some limitations. Since the study participants were not randomly selected and the sample size was 15 , findings cannot be generalized to all school resource officers in the U.S. However, it is expected that all school resource officers would have common experiences such as use of discretion, problems with school administration, and the prevalence of violence among youth. Thus, this study can provide some insights about the experiences of school resource officers from other States of the U.S.

In sum, school resource officers differ from other police officers by their perceptions and experiences for dealing with juvenile delinquency, because the frequency of their encounter with juveniles is greater than other police officers. Moreover, they have to deal with parents of juveniles which may make the situation more difficult. Working in the school gives them advantage for following delinquent trajectory of the offenders and their experiences may give a lot of information about juvenile's life course. In this regard, in order to help juveniles to establish their new lifestyle away from delinquency, the presence of school resource officers may help students to build new relationships with their friends and school staff. Hereby, the perception toward delinquent juveniles which see them as not teachable or not valuable can be solved by the effort of school resource officers' experience at dealing with delinquents. Further research in the area of school resource officers is needed to determine solutions to youth violence in schools. 
Taşğın, S., Demirkol, İ.C., \& Aksu, G. (2015). Perceptions of school resource officers on juvenile delinquents in schools. International Journal of Human Sciences, 12(1), 664-684. doi: 10.14687/ijhs.v12i1.3062

\section{References}

Barber, N. (2004). Single parenthood as a predictor of cross-national variation in violent crime. Cross-Cultural Research, 38, 343-358.

Biemer, P. P., Lyberg, L.E. (2003). Introduction to Survey Quality. New York: John Wiley \& Sons.

Brownfield, D., Thompson, K. (2008). Correlates of delinquent identity: Testing interactionist, labeling, and control theory. International Journal of Criminal Justice Sciences, 3(1), 44-53.

Clark, R.L. (2007). Public and professionals' views of the juvenile justice system in Georgia: A report on a general population poll and a web survey of professionals in the juvenile justice field. Retrieved November 22, 2009, from http://www.cviog.uga.edu/childfamilypolicy/publications/juvenilejusticeviews.pdf

Corbin, J., Strauss, A. (1990). Grounded theory research: Procedures, canons, and evaluative criteria. Qualitative Sociology, 13(1), 3-21.

Creswell, J.W. (2007). Qualitative inquiry. (2 $2^{\text {nd }}$ ed.). Thousand Oaks, CA: Sage.

Crouch, E., and Williams, D. (1995). What cities are doing to protect kids. Educational Leadership 52, 60-63.

Dinkes, R., Kemp, J., Baum, K., Snyder, T.D. (2009). Indicators of school crime and safety: 2008. Retrieved November 25, 2009, from http://nces.ed.gov/pubs2009/2009022.pdf

Dorn, R.A.V. (2004). Correlates of violent and nonviolent victimization in a sample of public high school students. Violence and Victims, 19(3), 303-320.

Fisher, C.J., Mawby, R.I. (1982). Juvenile delinquency and police discretion in an inner-city area. British Journal of Criminology, 22(1), 63-75.

Furlong, M., Babinski, L.,Poland, S., Munoz, J., Boles, S. (1996). Factors associated with school psychologists' perceptions of campus violence. Psychology in the Schools, 33, 28-37.

Johnson, L.M., Simons, R.L., Conger, R.D. (2004). Criminal justice system involvement and continuity of youth crime: A longitudinal analysis, Youth \& Society, 36(1), 3-29.

Johnson, I. M. (1999) "School violence: the effectiveness of a school resource officer program in a southern city", Journal of Criminal Justice, 27(2), 173-192.

I-SAFE (2009). Cyber Bullying: Statistics and tips. Retrieved November 25, 2009 from http://www.isafe.org/channels/sub.php?ch=op\&sub $\mathrm{id}=$ media cyber bullying

Klein, M.W. (1986). Labeling theory and delinquency policy: An experimental test. Criminal Justice and Behavior, 13(1), 47-79.

Kraus, J., Hasleton, S.L. (1982). Juvenile offensers' diversion potential as a function of police perceptions. American Journal of Community Psychology 10(2), 171-182.

Lambert, R. D. and McGinty, D. (2002) "Law enforcement officers in schools: setting priorities", Journal of Educational Administration, 40(3), 257-273.

Landau, S.F. (1981). Juveniles and the police. British Journal of Criminology, 21(1), 27-46.

Larson, J., Busse, R.T. (1998). Specialist-level preparation in school violence and youth gang intervention. Psychology in the Schools, 35(4), 373-379.

Lipsky, M. (1980). Street-level bureaucracy: Dilemmas of the individuals in public services. New York: Russell Sage Foundation.

Lotz, R. (2005). Youth crime: A modern synthesis in America. New Jersey: Pearson Prentice Hall.

May, D.C., Cordner, G., Fessel, S.D. (2004). School resource officers as community police officers: Fact or fiction. Law Enforcement Executive Forum, 4(6), 173-187.

Mears, D. P. (2001). Get though with juvenile offenders: Explaining support for sanctioning youths as adults. Criminal Justice and Behavior, 28(2), 206-226.

Miles, M.B., Huberman, A.M. (1994). Qualitative data analysis. ( ${ }^{\text {nd }}$ ed.). Thousand Oaks, CA: Sage.

NCES, (2013). Indicators of school crime and safety: 2013. Retrieved from http://nces.ed.gov/programs/crimeindicators/crimeindicators2013/ind_16.asp on February 10, 2015.

Piliavin, I., Briar, S. (1964). Police encounters with juveniles. The American Journal of Sociology, 70(2), 206-214. 
Taşğın, S., Demirkol, İ.C., \& Aksu, G. (2015). Perceptions of school resource officers on juvenile delinquents in schools. International Journal of Human Sciences, 12(1), 664-684. doi: 10.14687/ijhs.v12i1.3062

Ryan, L.G., Loessi, K.M., Nieri, T. (2007). Relationships with adults as predictors of substance use, gang involvement, and threats to safety among disadvantaged urban high-school adolescents. Journal of Community Psychology, 35(8), 1053-1071.

Sampson, R.J., Laub, J.H. (2005). A life-course view of the development of crime. Annals of the American Academy of political and Social Science, 602, 12-45.

Shadish, W.R., Cook, T.D., Campbell, D.T. (2002). Experimental and quasi-experimental designs for generalized causal inference. Boston: Houghton Mifflin Company.

Simons, R.L., Simons, L.G., Wallace, L.E. (2004). Families, delinquency, and crime: Linking society's most basic institution to antisocial behavior. Los Angeles: Roxbury.

Silverman, D. (2006). Interpreting Qualitative Data, (3 ${ }^{\text {rd }}$ ed.). Los Angeles: Sage.

Singleton, R.A., Straits, B.C. (2005). Approaches to social research. $\left(4^{\text {th }}\right.$ ed.). New York: Oxford University Press.

Snyder, H. N. (2005). Juvenile arrests 2003. Juvenile Justice Bulletin. Washington, D.C: Office of Justice Programs, Office of Juvenile Justice and Delinquency Prevention.

SRO (2009). SRO Survey, Retrieved November 22, 2009, from http://nasro.org/presentations/2009 SRO Survey.swf

Tannenbaum, F. (1938). Crime and the community. Boston: Ginn.

Trojanowicz, R.C., Morash, M., Schram, P.J. (2001). Juvenile delinquency: Concepts and control. (6 $\left.{ }^{\text {th }} \mathrm{ed}.\right)$, NJ: Prentice Hall.

United States Department of Justice. (1999) A national assessment of school resource officer programs. Washington, DC: National Institute of Justice.

United States Department of Justice. (2001). COPS: On the beat. Washington; DC: Office of Community Oriented Policing Services. School Safety Leadership Initiative. 